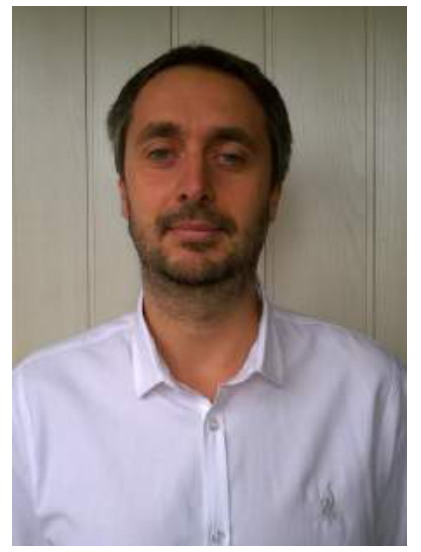

\author{
Мар'ян Марущак, \\ викладач, \\ Національний педагогічний університет \\ імені М.П. Драгоманова \\ (м. Київ)
}

\author{
Maryan Marushchak, \\ teacher, \\ National Pedagogical Dragomanov University \\ (Kyiv) \\ 979mara@gmail.com
}

УДК: 37.091.26:796.332]:04. ББК 74.267.5:32.97

\title{
ВИКОРИСТАННЯ КОМП'ЮТЕРНОГО ПРОГРАМНОГО ЗАБЕЗПЕЧЕННЯ ДЛЯ ОЦІНЮВАННЯ НАВЧАЛЬНИХ ДОСЯГНЕНЬ УЧНІВ 5-9 КЛАСІВ НА УРОКАХ ФІЗИЧНОЇ КУЛЬТУРИ В ПРОЦЕСІ НАВЧАННЯ ФУТБОЛУ
}

\section{THE USE OF COMPUTER SOFTWARE FOR THE EVALUATION OF EDUCATIONAL ACHIEVEMENTS OF PUPILS OF THE $5^{\text {TH }}-9^{\text {TH }}$ FORMS AT THE LESSONS OF PHYSICAL EDUCATION DURING THE PROCESS OF LEARNING TO PLAY FOOTBALL}

У статті обгрунтована методика оцінювання учнів основної школи на уроках фізичної культури під час навчання футболу, доведена залежність спеціальної рухової підготовленості у футболі від рівня розвитку окремих антропометричних психофізіологічних показників росту й розвитку організму, фізичної підготовленості та стану соматичного здоров'я учнів, представлена комп'ютерна програма «Електронний журнал з фізичної культури для учнів основної школи (варіативний модуль «Футбол»)», яка передбачає здійснення оцінки успішності учнів з усіх модулів, які входять до навчальної програми з фізичної культури 5-9 класів. Перелічено необхідні умови функціонування електронного журналу, описана послідовність його заповнення, подано зразок використання «Електронного журналу з фізичної культури для учнів основної школи» на прикладі учнів 5 класу. Підтверджено ряд позитивних змін у школярів основної школи після застосування запропонованої методики як у показниках мотиваційного компоненту, так і в технічних прийомах під час навчання футболу.

Ключові слова: комп'ютерна програма, електронний журнал, навчальні досягнення, інформаційні показники, оцінка, фізична культура, футбол.

The article substantiates the methodology of the evaluation of pupils of secondary school at the lessons of Physical Education during the process of learning to play football, proves the dependence of the special motor preparedness in football on the level of the development of individual anthropometric and psychophysiological indicators of pupil's height and body development, physical preparedness and the condition of pupil's somatic health. The article presents a computer program "Electronic magazine of Physical Education for pupils of secondary schools", which involves the evaluation of pupils" achievement in all sections of the curriculum of Physical Education of the 5th - 9th forms. The article lists the necessary conditions for the functioning of the electronic magazine, describes the sequence of its filling, shows an example of the use of "Electronic magazine of Physical Education for pupils of secondary schools" on the example of the pupils of the 5th form. A large number of positive changes among pupils of 5th - 9th forms have been confirmed after the application of the proposed methodology both in the indicators of the motivational component and the technical skill during football learning.

Key words: a computer program, educational achievements, electronic magazine, evaluation, football, information indicators, Physical Education.

В статье обосновывается методика оценки учащихся основной школы на уроках физической культуры во время обучения футбола, доказана зависимость специальной двигательной подготовки в футболе от уровня развития отдельных антропометрических, психофизиологических показателей роста и развития организма, физической подготовленности и состояния соматического здоровья учащихся, представлено компьютерную программу «Электронный журнал по физической культуре для учащихся основной школы», которая включает в себя оценки учеников всех модулей, которые включены в учебную программу физического воспитания 5-9 классов. Перечислены необходимые условия для функционирования электронного журнала, описана последовательность его заполнения, подано образец использования «Электронного журнала по физической культуре для учащихся основной школы (вариативный модуль «Футбол»)» на примере учащихся 5 класса. Подтверждено ряд положительных изменений в школьников 5-9 классов после применения предлагаемой методики как в показателях мотивационного компонента, так и в технических приёмах в процессе обучения футбола.

Ключевые слова: электронный журнал, информационные показатели, компьютерная программа, оценка, учебные достижение, физическая культура, футбол. 
Постановка проблеми в загальному вигляді та її зв'язок з важливими науковими та практичними завданнями. Зміст навчального матеріалу з футболу в 5-9 класах включає в себе вивчення базових елементів: ведення та зупинка м'яча, удари по м'ячу на дальність і точність, а також жонглювання м'ячем, що є спеціальною підвідною вправою для вивчення основних технічних елементів у цій спортивній грі [3, с.12]. При цьому вікова динаміка навчальних досягнень учнів середніх класів під час навчання футболу має певні особливості, характеризується гетерохронністю й певною відмінністю в розвитку спеціальної рухової підготовленості школярів, а також тісним взаємозв'язком між антропометричними даними, фізичними, психофіологічними показниками, соматичним здоров'ям та руховими тестами, які є необхідними для успішного навчання гри у футбол [2, с.16]. Володіння цими прийомами не тільки визначає високий рівень відчуття м'язових зусиль та інших необхідних видів координаційних здібностей дитини, а й служить характеристикою технічної підготовленості учня [8, с.18]. Необхідно відмітити, що контрольні вправи, запропоновані розробниками державної навчальної програми 3 фізичної культури для учнів основної школи, не дають повної інформації про успішність засвоєння всіх рухових дій, що вивчаються в конкретному класі, оскільки їх вибір не обґрунтований, не зрозуміло, на якій основі вони розроблені та яким чином диференціюються за рівнями навчальних досягнень [6, с.10]. Тому залежність спеціальної рухової підготовленості у футболі від рівня розвитку окремих антропометричних, психофізіологічних показників росту й розвитку організму, фізичної підготовленості та стану соматичного здоров'я учнів, а також недосконалість існуючих контрольних нормативів і вимог навчальної програми з фізичної культури для учнів 5-9 класів до навчальних досягнень школярів з варіативного модулю «Футбол» зумовлюють необхідність перегляду методики оцінювання засвоєння учнями основної школи рухових умінь і навичок.

Аналіз останніх досліджень і публікацій, у яких започатковано розв'язання проблеми. Аналіз спеціальної наукової вітчизняної та зарубіжної літератури в галузі фізичної культури й спорту показав, що, на думку багатьох авторів, найбільш адекватний вплив на процес формування рухових умінь і навичок учнів має встановлення індивідуальних норм спеціальної рухової підготовленості з врахуванням індивідуальних антропометричних, психофізичних особливостей розвитку організму та показників фізичної підготовленості й соматичного здоров'я кожної дитини [9,11,15 та ін.]. Найбільші можливості для цього, на їх думку, має використання інформаційно-комунікаційних технологій, призначених для автоматизованого визначення, збереження та аналізу результатів контролю й оцінювання успішності учнів. Вони дають можливість забезпечити оперативний зворотний зв'язок у системі «навчальний матеріал - учень», сприяють ефективному самоуправлінню й самоконтролю навчальної діяльності, дозволяють зробити процес навчання мобільним, строго диференційованим та індивідуальним, $є$ джерелом навчальної інформації, наочним посібником, засобом підготовки й зберігання тестів, діагностики та контролю [4, с.13].

Формування мети статті. Метою статті є обгрунтування ефективності застосування методики оцінювання учнів основної школи на уроках фізичної культури під час навчання футболу на основі розробленої комп'ютерної програми «Електронний журнал з фізичної культури для учнів основної школи (варіативний модуль «Футбол»)».

Виклад основного матеріалу дослідження з повним обґрунтуванням отриманих наукових результатів. Розроблена нами методика оцінювання навчальних досягнень учнів 5-9 класів на уроках фізичної культури в процесі навчання футболу базується на раціональному підході до оцінки індивідуального стану учнів основної школи. В основі розробки індивідуально доступних норм у фізичному вихованні покладено процес створення математичних моделей у вигляді регресійних рівнянь, де в якості змінних величин використовуються показники антропометричного або психофізичного розвитку, фізичних якостей, функціональних можливостей організму тощо. Змінні, що входять до математичних моделей, дозволяють вплинути на рівень розвитку основного досліджуваного показника в процесі фізичного виховання. Оперування подібними моделями дозволяє вчителеві фізичної культури вносити істотні корективи в навчально-виховний процес, підбирати зміст спеціальної підготовки учня з урахуванням індивідуального підходу, а найголовніше, здійснювати оцінку успішності учнів під час навчання різних фізичних вправ, зокрема футболу [8]. Надзвичайно значущим при визначенні навчальних досягнень учнів основної школи у футболі $€$ встановлення індивідуально можливих норм ігрових дій. Співставлення фактичного результату, що показує учень у контрольній вправі з індивідуально можливим результатом, не тільки дає характеристику технічної ігрової підготовленості учня, а й свідчить про наявність задатків та здібностей дитини до занять футболом [7, с.14]. Для розробки методики оцінювання учнів основної школи під час навчання футболу були розраховані рівняння множинної регресії для визначення індивідуальних технічних показників у футболі учнів 5-9 класів, де $Y \in$ показником техніки виконання окремої технічної ігрової дії у футболі, $\mathrm{X}_{1}-\mathrm{X}_{\mathrm{n}}$ - незалежні змінні, $\mathrm{k}_{1}-\mathrm{k}_{\mathrm{n}}-$ коефіцієнти регресії, a - вільний член. Використання цих модельно-цільових характеристик під час навчання футболу дозволяє об'єктивно оцінювати успішність учня на уроках фізичної культури. Підставляючи інформаційно-значущі індивідуальні антропометричні, психофізіологічні показники, а також показники фізичної підготовленості й стану соматичного здоров'я дитини у формулу, що відповідає конкретному віку та статі, можна кількісно точно визначити результат, який може показати учень у певній руховій дії у футболі [5].

Для більш швидкого обрахунку результатів, які учні отримали під час виконання різних технічних прийомів, нами була розроблена й представлена програма «Електронний журнал з фізичної культури для учнів основної школи (варіативний модуль «Футбол»)», яка передбачає здійснення оцінки успішності учнів 3 усіх модулів, які входять до навчальної програми з фізичної культури в основній школі (рис.1.). 


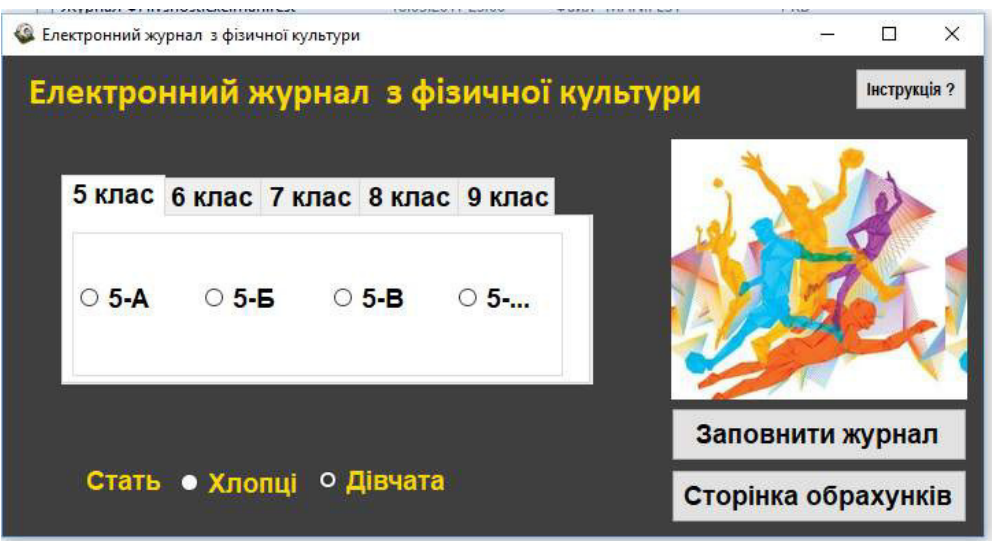

Рис.1. Електронний журнал з фізичної культури для учнів основної школи (варіативний модуль «Футбол»)

Перед використанням цієї програми необхідно визначити інформативно-значущі антропометричні, психофізіологічні показники, а також показники фізичної підготовленості й стану соматичного здоров'я учнів. На основі цих показників слід розрахувати рівняння регресії, які є однією з необхідних умов функціонування «Електронного журналу з фізичної культури для учнів основної школи (варіативний модуль «Футбол»)».

Для початку роботи з програмою «Електронний журнал з фізичної культури для учнів основної школи (варіативний модуль «Футбол»)» учитель вибирає клас, підвівши курсив мишки чи клавіатури на перемикач відповідного класу. Одночасно вчитель вибирає стать того учня, якого він буде оцінювати, клікнувши курсив на перемикач «хлопці» чи «дівчата». Потім вносить до журналу контингент класу, який оцінюється. Для цього слід за допомогою курсиву мишки чи клавіатури клікнути вікно «заповнити журнал». При натисненні на цю кнопку з'являється нове вікно. У цьому вікні $€$ такі кнопки як «додати учня», «модуль футбол», «модуль гімнастика», «модуль гандбол» та інші. Учитель спочатку натискає кнопку «додати учня», а потім заповнює поля таким чином: спочатку вказується порядковий номер за списком, прізвище, ім'я і по батькові, після цього вчитель натискає внизу екрана кнопку «додати учня». У правому вікні з'являється порядковий номер, прізвище, ім'я та по батькові учня. Таким чином формується список учнів відповідного класу (рис.2.).

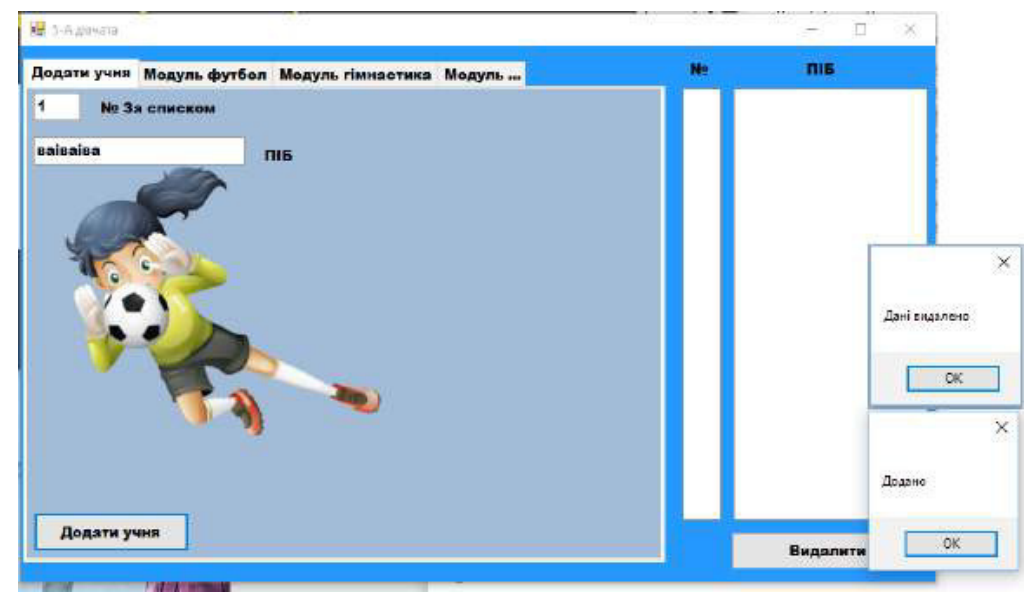

Рис.2. Формування контингенту учнів класу в «Електронному журналі з фізичної культури для учнів основної школи (варіативний модуль «Футбол»)»

Сформувавши список учнів класу, вчитель вибирає модуль, який він планує оцінювати, клікнувши на одну із кнопок «модуль футбол», «модуль гімнастика», «модуль гандбол» чи на інший модуль. Вибравши, наприклад, «модуль футбол», на екрані з'являється перелік антропометричних, психофізіологічних особливостей організму, показники фізичної підготовленості та соматичного здоров'я учня відповідного класу. Напроти кожного із цих показників розташоване порожнє вікно, куди вчитель повинен вставити результат, показаний учнем. Відповідні показники є інформативно- значимими для кожного з технічних прийомів під час навчання футболу. Для цього вчитель перед початком навчання цього модуля здійснює обстеження учнів (рис.3.)

Запропонована програма дає можливість не одразу, а поступово заповнювати порожні вікна, натискуючи кнопку «додати дані». Після заповнення усіх порожніх вікон на екрані необхідно відкрити перше вікно й натиснути кнопку «сторінка обрахунків», яка знаходиться під кнопкою «заповнити журнал». Після кліку на цю кнопку на екрані з'являється нове вікно, у якому в верхній частині екрану розташовані вікна «модуль футбол», «модуль гімнастика» та інші. Учителю необхідно вибрати, який модуль він планує оцінювати. Вибравши, наприклад, «модуль футбол», на екрані з'являється 
перелік технічних прийомів, які слід оцінити, та порожні вікна, куди необхідно ввести результат, що показав учень під час здачі нормативу. Потім за аналогією з вікном «додавання учня» обираємо необхідного нам учня та вводимо дані про його фактичні результати в текстові поля (перший лівий рядок). При цьому за допомогою регресійних рівнянь автоматично заповнюються текстові поля «прогнозований результат». Цей результат учень може показати, виходячи з його фізичного розвитку, загальної фізичної підготовленості та рівня соматичного (фізичного) здоров'я.

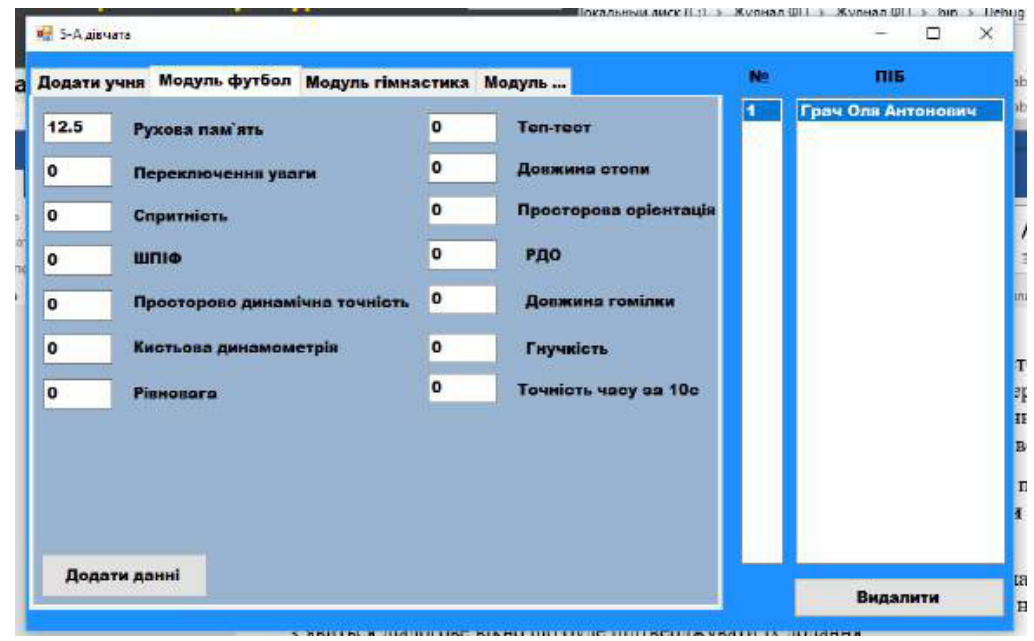

Рис.3. Приклад заповнення інформативно-значимих показників фізичного стану для технічної підготовленості учнів у процесі навчання футболу

Після заповнення всіх порожніх вікон учитель повинен натиснути на кнопку «обрахувати», внизу в порожньому вікні з'являється кількість балів за 12-бальною шкалою, отриману учнем внаслідок співставлення можливого й фактичного результатів (рис.4.).

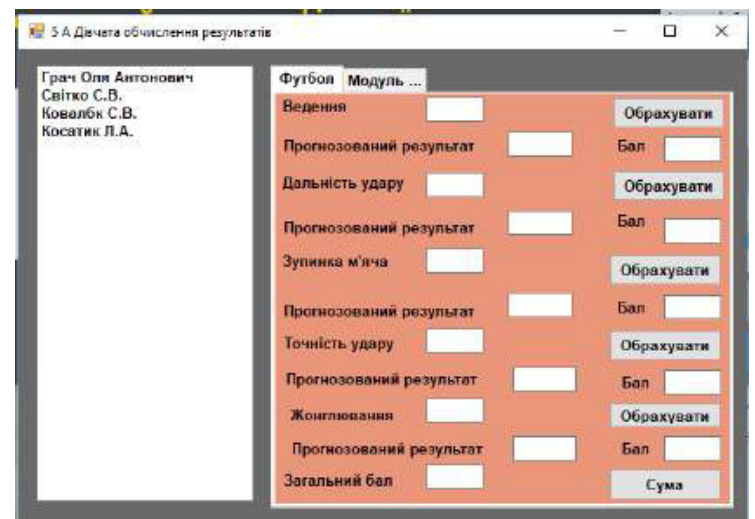

Рис.4. Обрахунки результатів в «Електронному журналі з фізичної культури для учнів основної школи»

Натиснувши на кнопку «сума», у порожньому вікні з'являється загальна сума балів, яку учень отримав за модуль «Футбол». Загальна сума балів вираховується додаванням суми балів, отриманих учнем за кожний технічний прийом, поділивши отриману суму на 5, тобто кількість технічних прийомів, які оцінюються. Сума балів вираховується за 12-бальною шкалою.

При цьому в програмі використовуються такі позначення:

$Y_{\text {tp }}$ - можливий (належний) результат виконання певного технічного прийому учнем відповідно до антропометричних та психофізіологічних показників розвитку його організму; $\mathrm{Yf}_{\text {tр }}$ - фактичний результат виконання учнем певного технічного прийому; $\Delta$ - відхилення можливого результату виконання технічного прийому від фактичного. Співставлення можливого й фактичного результатів виконання технічних прийомів базується на врахуванні характеру залежності зв'язків між показниками: прямого чи оберненого. Так, співвідношення $\mathrm{Y}_{\mathrm{tp}} / \mathrm{Yf}_{\mathrm{tp}}$ використовувалося у випадку оберненої залежності між показниками. Наприклад, при визначення успішності ведення м'яча, оскільки чим менший результат у секундах показує учень, тим вищою $є$ його швидкість ведення. В іншому випадку використовувалося співвідношення $\mathrm{Yf}_{\mathrm{tp}} / \mathrm{Y}_{\mathrm{tp}}$.

Необхідно відмітити, що учитель при бажанні або потребі може перевірити заповнення всіх результатів. Для цього мишкою слід потягнути вниз нижню частину вікна (рис. 5). 


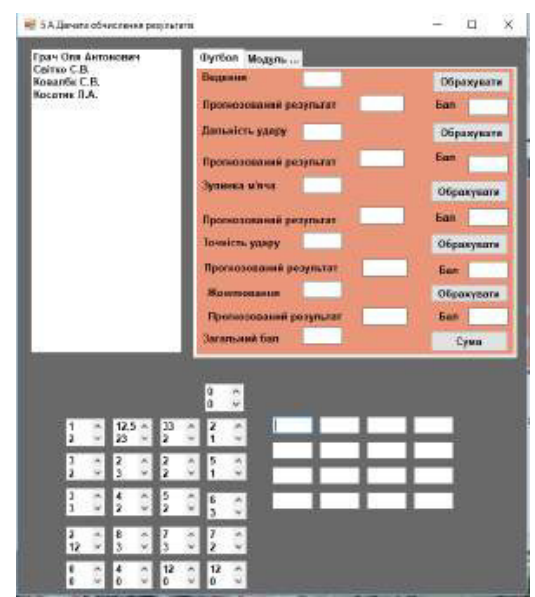

Рис. 5. Вікно з перевіркою введення результатів

Використання «Електронного журналу з фізичної культури для учнів основної школи (варіативний модуль «Футбол») можна показати на прикладі учнів 5 класу. На початку навчального року перед початком вивчення модуля «Футбол» учитель здійснює вхідне тестування для визначення інформаційно-значимих індивідуальних антропометричних, психофізіологічних показників, а також показників фізичної підготовленості й стану соматичного здоров'я дитини для основних технічних прийомів, що вивчаються учнями на уроках фізичної культури. Визначені показники фізичного стану учнівської молоді записуються в електронний журнал у порожні клітинки, які відповідають тому чи іншому показнику фізичного стану учня. Необхідно заповнити всі порожні віконця, оскільки в іншому випадку програма працювати не буде. Записавши всі показники фізичного стану хлопчиків чи дівчаток, у кінці розучування модуля «Футбол» учитель здійснює тестування рівня технічної підготовленості учнів, заповнюючи також порожні віконця, що відповідають тому чи іншому технічному прийому. Таким чином учитель визначає фактичний результат, який учень отримав у кінці навчання футболу. Програма автоматично співставляє можливий результат з фактичним і за допомогою формули визначається кількість балів, яку учень отримав за виконання того чи іншого технічного прийому. Коли буде здійснена оцінка всіх технічних прийомів, що вивчаються, тільки в цьому випадку програма виводить на екран загальну оцінку, яку учень отримав за модуль «Футбол».

Ефективність використання програми «Електронний журнал з фізичної культури для учнів основної школи (варіативний модуль «Футбол»)» була підтверджена під час проведення формувального педагогічниого експерименту на базі загальноосвітніх шкіл. В експерименті взяли участь учні 5-9 класів, які були поділені на експериментальну та контрольну групи (ЕГ,КГ). Застосування запропонованої методики під час навчання рухових дій з футболу виявило ряд позитивних змін як у показниках мотиваційно-цінносного компоненту, зокрема, відвідуваність занять у хлопців 5-9 класів загальноосвітніх навчальних закладів підвищилася на 13,35\%, а у дівчат - на 17,78 \%, кількість учнів, які вважають, що їх успішність під час вивчення футболу в школі на уроках фізичної культури об'єктивно оцінюється, збільшилась на 27\% (при р<0,05), так і в технічних прийомах учнів середніх класів загальноосвітніх шкіл, де за всіма показниками спеціальної рухової підготовленості спостерігається достовірне збільшення результатів в експериментальній групі по відношенню до контрольної групи (при р<0,05). Це відбувається внаслідок наявності доступного нормативу, який дає можливість за рахунок старанності в навчанні отримати високий результат, що, у свою чергу, мотивує школяра, він більш наполегливо й свідомо виконує вправи, що призводить до покращення показників спеціальної рухової підготовленості [1, с.17].

Висновки і перспективи подальших досліджень. На основі проведених досліджень розроблене програмне забезпечення оцінювання навчальних досягнень учнів основної школи, яке представлене у вигляді «Електронного журналу з фізичної культури для учнів основної школи (варіативний модуль «Футбол»)». Запропонований журнал дає можливість здійснювати оцінювання успішності учнів з усіх модулів, що входять до навчальної програми 3 фізичної культури школярів з урахуванням їх фізичного стану. Представлена інструкція щодо користуванням цим журналом, яка значно полегшує його застосування учителями на уроках фізичної культури. Проведене дослідження не вичерпує всіх аспектів удосконалення методики оцінювання успішності учнів основної школи під час навчання футболу з використанням інформаційно-комунікаційних технологій. На його основі буде здійснюватися подальший пошук шляхів підвищення ефективності процесу педагогічного контролю й оцінювання навчальних досягнень з усіх модулів, що входять до навчальної програми учнів 5-9 класів на уроках фізичної культури, будуть досліджені умови підготовки майбутніх учителів фізичної культури до використання комп'ютерного програмного забезпечення в процесі фізичного виховання школярів.

1. Безверхня Г. В. Мотивація до занять фізичною культурою і спортом школярів 5-11 класів : автореф. дис. ... на здобуття наук. ступеня канд. пед. наук.: спец. 24.00.02. "Фізична культура, фізичне виховання різних груп населення" / Г. В. Безверхня. - Львів. - 2004. - 22 с.

2. Васильчук А.Г. Автоматизована система комплексного контролю за фізичним вихованням (На прикладі уроку з футболу). // Фізичне виховання в школі. 2006. - №6. - С. 17-20. 
3. Зубалій М.Д. Розвиток змісту навчального матеріалу з фізичної культури // Нова педагогічна думка: науково-методичний журнал. - Рівне, 2013. - №4 (76). - С.115-118.

4. Кадемія М.Ю., Шахіна І.Ю. Інформаційно-телекомунікаційні технології в навчальному процесі: Навчальний посібник / М.Ю.Кадемія, І.Ю. Шахіна / - Вінниця: ТВО «Планер». - 2011. - 220 с.

5. Кудін А.П., Тимошенко О.В., Володько І.В., Мішаровський Р.М., Жабєєв Г.В. Використання мультимедійних дидактичних засобів навчання на уроках фізичної культури в школі / А.П. Кудін, О.В.Тимошенко, І.В.Володько, Р.М. Мішаровський, Г.В. Жабєєв // Науковий часопис НПУ імені М.П. Драгоманова. Серія 15 «Науково-педагогічні проблеми фізичної культури (фізична культура і спорт)». - К.: Вид-во НПУ імені М.П. Драгоманова, 2011. - Випуск 10. - С. 440-444.

6. Марущак М.О. Особливості вікової динаміки загальної та спеціальної фізичної підготовленості учнів основної школи в процесі вивчення футболу // Науковий часопис НПУ імені М.П.Драгоманова. - Серія 15: Науково-педагогічні проблеми фізичної культури (фізична культура і спорт). - Т.3. - 2017. - №15. - С. 284-288.

7. Митчик О.П. Індивідуалізація фізичного виховання підлітків у загальноосвітній школі: Автореф. дис. ... канд. наук з фіз. виховання і спорту: 24.00.02 / Львівський держ. ін-тут фіз. культури. - Львів, 2002. - 20 с.

8. Мішаровський Р.М. Визначення найбільш інформативних показників під час навчання спеціальних умінь учнів молодшого шкільного віку на уроках з футболу в школі. Науковий часопис НПУ ім. М.П. Драгоманова. Київ., 2010. - Випуск № 6. Серія №15. - С. 184-188.

9. Сітовський А. М. Диференційований підхід у фізичному вихованні підлітків з різними темпами біологічного розвитку (на прикладі школярів 7-х класів) : автореф. дис. на здобуття наукового ступеню канд. наук з фізичного виховання і спорту : спец. 24.00.02 «Фізична культура, фізичне виховання різних груп населення» / А. М. Сітовський. - Львів, $2008 .-20$ с.

10. Тимошенко О.В., Дьоміна Ж.Г. Стан та основні напрями модернізації системи фізичного виховання школярів на сучасному етапі розвитку суспільства / Фізичне виховання у сучасній школі// науково-методичний журнал. - 2011. №6. - С.2-5.

11. Тюх І. А. Індивідуальні норми фізичної підготовленості молодших школярів у процесі фізичного виховання. : автореф. дис. на здобуття наук. ступеня канд. наук з фіз. виховання і спорту : спец. 24.00 .02 «Фізична культура, фізичне виховання різних груп населення» / І. А. Тюх. - К., 2009. - 20 с.

12. Benk G. Football training program. - New York, 1991. - 226 p.

13. Bunker D. I., Thorpe R. D. (1982). A model for the teaching of games in secondary school. Bulletin of Physical Education, 18, 5-8.

14. Craggs C., Corder K, van Sluijs, E.M. and Griffin S., (2011). Determinants of change in physical activity in children and adolescents: a systematic review. American journal of Preventive Medicine, 40(6), pp. 645-658.

15. Latsh M. L. Control of human movement. - Champaign ; Illinois : Human Kinetics, 1993. - P. 38 - 40.

16. Mallo J. Physical load imposed on soccer players during small-sided training games/ J. Mallo, E. Navarro // J Sports Med Phys Fitness, 2008.- Vol. 26, № 2.- P. 81-89.

17. Mandigo J., Holt N., Anderson A., Sheppard J. (2008) Children's motivational experiences following autonomy-suportive games lessons. European Physical Education Review, 14, 407-425.

18. Wilmore J.H., Costill D.L. Physiology of sport and exercise. - Champaign: Human Kinetics, 1994. - 549 p.

\section{Reference}

1. Bezverkhnia H. V. Motyvatsia do zaniat' fizychnoyu kul'turoyu i sportom shkoliariv 5-11 klasiv : avtoref. dys. na zdobuttia nauk. stupenia kand. ped. nauk : spets. 24.00.02 "Fizychna kul'tura, fizychne vyhovannia riznyh grup naselennia" / H.V. Bezverkhnia. Lviv. - 2004. - $22 \mathrm{~s}$.

2. Vasyl'chuk A.H. Avtomatyzovana systema kompleksnoho kontrolyu za fizychnym vykhovanniam (Na prykladi uroku z futbolu). // Fizychne vykhovannia v shkoli. 2006. - №6 - S. 17-20.

3. Zubaliy M.D. Rozvytok zmistu navchal'noho materialu z fizychnoyi kul'tury // Nova pedahohichna dumka: naukovo -metodychnyy jurnal. - Rivne, 2013. - №4 (76). - S.115-118.

4. Kademia M.Y., Shakhina I.Y. Informatsiyno - telekomunikaciyni tekhnolohiyi v navchal'nomu protsesi: Navchal'nyy posibnyk / M.Y. Kademia, I.Y. Shakhina / - Vinnytsia: TVO "Planer". - 2011. - 220 s.

5. Kudin A. P., Tymoshenko O. V., Volod'ko I.V., Misharovskyy R.M., Jabeyev H.V. Vykorystannia mul'tymediynykh dydaktychnykh zasobiv navchannia na urokakh fizychnoyi kul'tury v shkoli / A. P. Kudin, O. V. Tymoshenko, I.V. Volod'ko, R.M. Misharovskyy, H.V. Jabeyev // Naukovyy chasopys NPU imeni M.P. Drahomanova. Seriya 15 "Naukovo-pedahohichni problemy fizychnoyi kul'tury (fizychna kul'tura i sport)". - K.: Vyd-vo NPU imeni M.P. Drahomanova, 2011. - Vypusk 10. - S. 440-444.

6. Marushchak M.O. Osoblyvosti vikovoyi dynamiky zahal'noyi ta special'noyi fizychnoyi pidhotovlenosti uchniv osnovnoyi shkoly v protsesi vyvchennia futbolu // Naukovyy chasopys NPU imeni M.P. Drahomanova. Seriya 15 "Naukovo-pedahohichni problemy fizychnoyi kul'tury (fizychna kul'tura i sport)". - T.Z. - 2017. - №15. - S. 284-288.

7. Mytchyk O.P. Indyvidualizatsiya fizychnoho vykhovannia pidlitkiv u zahal'noosvitniy shkoli: Avtoref. dys. ... kand. nauk z fiz. vykhovannia i sportu: 24.00.02 / Lvivskyy derj. in-tut fiz. Kul'tury. - Lviv , 2002. - 20 s.

8. Misharovskyy R,M. Vyznachennia naybilsh informatyvnykh pokaznykiv pid chas navchannia spetsialnykh umin' uchniv molodshoho shkil'noho viku na urokakh futbolu v shkoli. Naukovyy chasopys NPU imeni M.P. Drahomanova. Kyiv. 2010. - Vypusk №6. Seriya №15. . - s. 184-188.

9. Sitovskyy A.M. dyferentsiyovanyy pidhid u fizychnomu vykhovanni pidlitkiv z riznymy tempamy biolohichnoho rozvytku (na prykladi shkoliariv 7-kh klasiv) : avtoref. dys. na zdobuttia nauk. stupenia kand. ped. Nauk z fizychnoho vykhovannia i sportu : spets. 24.00.02 "fizychna kul'tura, fizychne vykhovannia hrup naselennia" / A.M. Sitovskyy. - Lviv, 2008. - 20s.

10. Tymoshenko O.V., Diomina J.H. Stan ta osnovni napriamky modernizatsiyi systemy fizychnoho vykhovannia shkoliariv na suchasnomu etapi rozvytku suspil'stva / Fizychne vykhovannia u suchasniy shkoli // naukovo-metodychnyy jurnal. - 2011. №6. - s.2-5.

11. Tiukh I.A. Indyvidualni normy fizychnoyi pidhotovlenosti molodshykh shkoliariv u protsesi fizychnoho vykhovannia : avtoref. dys. na zdobuttia nauk. stupenia kand. ped. nauk z fizychnoho vykhovannia i sportu : spets. 24.00.02 "fizychna kul'tura, fizychne vykhovannia hrup naselennia" / I. A. Tiukh. - K., 2009. - 20 s.

Рецензент: О.В.Тимошенко, доктор педагогічних наук, професор, Національний педагогічний університет імені М.Драгоманова 